\title{
The Exploitation of Patriarchal Society with Reference to Mahesh Dattani's Where There's a Will - Paradigm Shift
}

Sankar $\mathbf{G}^{1 *}$ and Sherly Hephzhibah $\mathrm{J}^{2}$

${ }^{1}$ Department of English, PSG College of Technology, Coimbatore, India

${ }^{2}$ Sathyabama Institute of Science and Technology, Chennai, India

\begin{abstract}
This research paper is aim to attempt exploitation in the male dominated society and it is also expressed the sufferings of transgender in the postmodern world. How the term patriotism has been used by Mahesh Dattani, in his notable Play Where There's a Will. It has been strikingly didactic and also a comic sense of his play. The theme reflects on the ordinary and everyday conflicts of middle class and upper class Indian families and comments on the role of money in the family relationships. The play explores a satire of patriarchal code and moral philosophy. The play is set in contemporary Gujarati society. This is a patriarchal family in which, the eldest male, has the greatest power and he controls and dominates his family through his will during and after his life. It deals with how the women characters exploited from the Patriarchal Society.
\end{abstract}

Keywords: Exploitation; Patriarchal Society; Transgender; Indian families

\section{Introduction}

The word 'patriarchy' literally means the rule of father or the patriarch Family Relationships, Moral Philosophy and originally it describes a specific type of 'male-dominant' structure or institution. Patriarchy is a characteristic form of social organization in which male is the family head and title is traced through the male who is older or higher in rank. Women are largely excluded from it. This dominant ideology is termed as patriarchy. Women are sub-ordinate to men, who is common in large part of the world and the men as superior to women. Patriarchy is a often used term in everyday conversation. The question here is "what is patriarchy?" In casual conversation, whether in English or any other language the term implies "male domination", "male prejudice (against women)", or more simply male power". The term means "the absolute rule of the father or the eldest male member over his family". Patriarchy is thus the rule of the father over all women in the family and also over younger socially and economically subordinate males. Literally, patriarchy means rule by the male head of a social unit (like family, tribe). However, since the early twentieth century, feminist writers have used the term patriarchy as a concept to refer to the social system of masculine domination over women. Patriarchy has been a fundamentally important concept in gender studies.

Patriarchy has been viewed as more than just the subordination of women. It has been pointed out that not all men are powerful in a patriarchal system. For example younger men in the family have less authority and power than older men. They have to defer to older men till their turn to exercise power comes. The lower class and underprivileged men, and in the Indian context the 'dalit' men have lesser or no authority as compared to the more privileged upper caste men. Such men who are oppressed and exploited by powerful men are denied access to resources of the society as well as their own masculine identity. Inspite of this, certain classes and some category of men are the targets of patriarchal authority, the fact remains that all men can claim resources and power more easily than women in their families or communities [1].

Where There's a Will is strikingly didactic and also a comic play. The theme reflects on the ordinary and everyday conflicts of middle class and upper class Indian families and comments on the role of money in the family relationships. The play explores a satire of patriarchal code and moral philosophy. The play is set in contemporary Gujarati society. This is a patriarchal family in which, the eldest male, has the greatest power and he controls and dominates his family through his will during and after his life.

Mahesh Dattani is considered as a queer fish by the upholders and guardians of Indian culture as supreme and unique entity on the face of the earth. He had to face the wrath of such guardians for bringing in to the open those issues which the hypocritical Indian society and culture tends to hide under the carpet, because they are uncomfortable. He daringly discusses the uncomfortable issuses on stage with much ease. Rachel Bari and Ibrahim Khalilullah in Reading Dattani state their view on Dattani's craftsmanship as follows:

Now what makes Dattani relevant and important to an individual who has seen today and is more interested in knowing what it means and why is it so are issues in his plays. His plays burn with social relevance. Issues of sexuality, hijra, homosexuality, child sexual abuse, hypocrisy about AIDS, religious intolerance, gender bias, social stereotyping or even what constitutes the contemporary Indian family. You name it, it is there: our modern social problems. For the modern Indian, this is familiar: one is on comfortable ground. Whatremains is the need to know why. Here Dattani scores above others, for today's need is exactly that today to know and lead a better tomorrow and not just yesterday. Interestingly Dattani's today does peep in to the past, but not of myth but of reality [2].

In the play Where There's a Will, he deals with the untouched and abnormal familial issues. The action starts with Hasmukh overhearing his son, Ajit complaining about his father's refusal to invest in new business ventures proposed by him. In a series of straight addresses or asides to the audience, Hasmukh clarifies that he had thrown away his

*Corresponding author: Sankar G, Department of English, PSG College of Technology, Coimbatore, India, Tel: 0422-2572177; E-mail: India.sankarliterature@ gmail.com

Received July 04, 2018; Accepted July 16, 2018; Published July 21, 2018

Citation: Sankar G, Hephzhibah JS (2018) The Exploitation of Patriarchal Society with Reference to Mahesh Dattani's Where There's a Will - Paradigm Shift. Arts Social Sci J 9: 383. doi: 10.4172/2151-6200.1000383

Copyright: $\odot 2018$ Sankar G, et al. This is an open-access article distributed unde the terms of the Creative Commons Attribution License, which permits unrestricted use, distribution, and reproduction in any medium, provided the original author and source are credited. 
son's project proposals unread because he is prejudiced that Ajit would lead them to extreme poverty. Neither does Hasmukh have any love to spare for his wife Sonal or for his daughter-in-law Preeti whom he briefly describes as sly snake and sums her up as a girl who has an eye of money. Hasmukh is not quite happy with his son's attitude. He expects him to do the same as he did to his father, which is unconditional submission. Hewants his son to be the exact replica of him. Hasmukh boasts that he is a self-made man. From his asides to the audience it is clear that he is not loyal to his wife. He has a mistress, who is brainy and works in his own company and resides in the company's flat, which is quite close to Hasmukh's bungalow. It is evident from the play that Hasmukh is a diabetic and cardiac patient with a history of high blood pressure, high cholesterol and an enlarged heart. Despite is ill-health he fags and boozes at his will. And they eventually lead him to his death at the end of the first scene.

Hasmukh's ghost lingers on in the house, wandering through its walls keeping on passing sarcastic comments on the action and attitudes of the other characters, though unheard by and invisible to them. The ghost of Hasmukh assumes the role of mock-chorus. The complication of the comedy emerges in the second scene in which it is revealed that none of his expectant family members have inherited his property but he has formed a Trust with his mistress Kiran Jhaveri as its Trustee and he has made a provision in the Trust to give meager monthly allowance to his family members as per his unique will. Moreover, Ajit must be in the office from 9 am to $6 \mathrm{pm}$ under the guardianship of Kiran Jhaveri and when he reaches forty-five years of age then the Trust would dissolve automatically and Ajit would inherit the trust's holdings. If he fails to do, the properties of Hasmukh Mehta Charitable Trust will be distributed to the charities. Hasmukh's will specifies that his former mistress will move in and live in his family till the Trust is dissolved [3].

Hasmukh has designed his will so as to dominate his family even after his death and to make his son live in his own image. It is revealed that Mrs. Sonal Mehta had lived her life under the total dominance of her sister Minal, who dictated her every move. The plot of the play is given a twist by the revelation of the fact to Kiran that Preeti had actually hastened the death of Hasmukh in order to inherit property. Kiran holds the truth against Preeti not to blackmail her, but to achieve a proper comic resolution by which the wife bonds with the husband, and the family bonds with Kiran and the ghost of Hasmukh leaves the house forever. Each of the family members having discovered his or her own identity finally separate from Hasmukh's overpowering self.

Hasmukh is a sort of domineering character. He wants to run the show as his father did. Hence he dismisses proposal made by his son. Hasmukh is of opinion that his son is a fool and he is self-made man. Moreover his son, Ajit can become a wise man like him only if he heeds to his words and acts accordingly. When Ajit rejects his advice and acts on his own by coming up with business proposals, Hasmukh expresses his regret for making him the Joint Managing Director for his group of companies. Hasmukh is of opinion that if he has heeded to the advice of Ajit and entered in new business ventures then he would not be there sticking around. And this is clear from the following conversation:

AJIT (on the phone): Five lakhs. That's all. Give me five lakhs and I'll modernize the whole bloody plant. That's what I tell my dad. I mean, come on, five lakhs is nothing!

HASMUKH (To the audience): My son, business man. Just listen to him

AJIT: I mean, it's not as if I want the money for myself. It's for his factory. But he just won't listen to me. (Collected Plays 455).
Hsamukh tries to control and exert his patriarchal authority over his son. But his non-relenting son defies his power and criticizes his own father for not listening to him all his life. Furthermore, he asserts his position as the Managing Director and demands audience. When Hasmukh finds that his son is non-relenting to his wishes, he considers him as an idiot and insults him by ignoring him and turning deaf ear to his business proposals.

Hasmukh is prejudiced against his own son. As he thinks him as an idiot, he regrets for begetting such a son. He goes to the extent of praying to god to make him drop dead. He then repents for praying so and he places another plea to god, which is to make him him a vegetable, so that he would not interfere in his business. He regretfully says that ever since he entered the portals of his company, he has been a problem. Hasmukh is of view that his son is a spendthrift and he is not matured enough to enter into realm of business. In addition, Hasmukh thinks that his son's business proposals are just foolish because he has not learnt the trade under his tutelage [4].

Hasmukh is of the notion that his daughter-in-law is charming, graceful and crafty. He says that Preeti, his daughter-in-law is crafty because he has deduced that only a willy person would agree to marry a person like his son. He further says that she has an eye on his money. Hasmukh is distressed to find his son an idiot and his daughter-inlaw a schemer. Hasmukh is not happy about the situation around him. He wants everything under his control, but to his dismay, he finds everything out of his control. And it puts him under a lot of stress. Hasmukh says:

That's my daughter-in-law, Preeti. Pretty, charming, graceful and sly as a snake... But she is an intelligent girl, I can tell you. She has her eye on my money. Why else would she agree to marry a dead loss like my son? (Lights a cigarette). My son isn't really after my wealth. That's because he doesn't have any brains... In the old days, if you said someone had a large heart, you meant he was generous and loving. (Collected Plays 456).

Ajit strongly believes that he would inherit all the wealth of Hasmukh, when Hasmukh is dead and gone. Ajit comes to such conclusion because his father refuses to budge in to have his way. Through his rebellion, he could only defy his father's authority and could achieve nothing more than that. He finds his father to be headstrong. And that leaves him no other hope than to wait patiently for his father's dismissal from the world.

Hasmukh underestimates his son's talents. He thinks that is son is foolish and he compares his son's talents to a plague to his company. He hates to discuss his company's secrets. When he finds his son discussing his company's secret to a friend of his, Hasmukh gets irritated. When Ajit boasts to his friend Deepak about the praise of the excise inspector about his knowledge the company, Hasmukh goes wild. Moreover, Hasmukh finds his son's attitude from his friend interfering in his business by flirting with his typists and he hates that He deduces his son's attitude from his friend's.

Hasmukh goes to the extent of insulting his son in front of his friend for not being compliant to his authority. He hates his son for rebelling against his face. Hasmukh considers as an insult and he could not just pocket it. He tries hard to make his son a compliant to his authority.

Ajit gets offended by hisfather's rebuke in front of his friend and he confronts his father saying that he is encroaching upon his space and he has no right to do so. But Hasmukh gives him a refutation that he 
has every right to do so because he is the owner of everything and he is the boss who runs the show and everybody including Ajit is supposed to play the role of puppets.

When Ajit puts forth a question regarding his rights, Hasmukh says that he has right to remain silent and obey his orders.

Hasmukh finds his son to be a stiff-necked, arrogant fool, who defies his authority. He is of view that he is never wrong because he listened to his father's words and he finds his son to contradict his views. Out of fear and frustration he tries to chastise his son but to no success. Hence he goes to the extent of concerning him by insulting him in front of his friend and he even slaps him in front of his wife.

Ajit arrives to a conclusion that is father cannot be satisfied at any rate. Moreover, he is a fault finder. He thinks that his father's prejudiced attitude towards him is the outcome of his deprived child wood and his jealousy over his own son, who gets everything too easily. Ajit fails to understand that his father is involved in the power politics and he would go to any extent to be victorious.

Ajit accuses his father that he corners him in order to turn the show as the boss as long as he could and after his death he wishes to do the same through him. Furthermore he says that he would not play his father because he would lose his identity, which he cannot afford to lose. Hasmukh retorts that if Ajit insists to be himself then he would be a big failure and the compares him to the numerical zero, which is nothing without any other number in front of it and he states him in plain terms that he is the number one who could makes his zeros valuable. Hasmukh urges his son to put him ahead in his life. Ajit is more concerned about his identity rather than his success. Hence he refuses to give way to his father. He cherishes his identity as unique and important thing, which is far more valuable than his dear life.

Ajit refuses to accept that his father is number one and he could transform his life from worse better. It is so because he finds nothing wrong in his life and he feels okay with it. Hasmukh never gave him a chance to estimates his assets liabilities. He has been dismissing his business proposals out rightly without even giving a second thought.

Sonal makes orange-flavoured halwa for his son, who just loves it. Hsamukh too loves it but he cannot eat it because of his dietary restriction due to his diabetes. As he could not eat halwa, he insists on not making it. He directs his daughter-in-law to instruct his wife that not to make halwa anymore. But Ajit that he loves to eat halwa. When Preeti informs him that his eating halwa should upset him [5].

It's the evident that Hasmukh tries to exert his authority over his family. He goes to the extent of dictating that what others should do and eat despite their likes and dislikes. Hasmukh could not tolerate his son's disregarded for him. The harder he tries the harder his son rebels his authority. He could not make his son fit into his mould.

Hasmukh is of opinion that his marriage with Sonal is the greatest tragedy in his life and his son Ajit is another tragedy. He swanks that is one of the richest men in the city and he became rich exclusively by his own efforts. He compares himself with his son and says that he is success and on the contrary, his son is a failure. In addition he says that he was a responsible man at his son's age, unlike his son. Hasmukh says:

When I was twenty-one, the greatest tragedy of my life took place. I got married to my wife, Sonal. You will meet her. The following year Ajit was born. Tragedy after tragedy. Still, they proved lucky, I suppose. Within no time we were running a very successful export house. Mehta
Exports. And then another-Ajit Exports. My wife insisted I name it after him. Today, I Hasmukh Mehta am one of the richest men in the city. All by my own efforts. Forty-five years old and I am a success in capital letters. Twenty-three years old and he is on the road to failure in bold capital letters [2].

Sonal insists that a dinner without paratas is incomplete and offers to make it. But Hsamukh insists that nobody wants paratas. On hearing it, Sonal says that Ajit would like it. But Hasmukh contradicts her. When they ask opinion he thinks for a moment and says that he needs it and Sonal goes back to the kitchen victoriously to make paratas. Hasmukh accuses Ajit as a liar and he says that he does not need them. To which Ajit retorts that he does not want them and he would rather lie than agree with them. It is ready to suffer in defying it rather than accepting it and loose his uniqueness. Ajit proves himself as a rebel against his father's hegemony in his own way.

In Hasmukh absence, Sonal and Preeti talk about Hasmukh's queer nature. Sonal is of the view that money has made him stubborn but Preeti is of the opinion that due to his achievements he has become proud and stubborn. Sonal adds that Hasmukh is not only proud but he thinks that he is a king and is family members are his subjects. She compares him to a crow, who painted itself white to become swan. It is evident that Hashmukh does not treat his family members as they are. He treats everybody in his house as his subjects. Sonal and Preeti resent the authority of Hasmukh but they are left without any option to show their opposition.

Hasmukh is of the opinion that sons are not living up to the expectation of their fathers. It was not the case in his days, when sons would venerate their fathers. And he is such a son, who lived up to his father's expectation. But he finds his son to defy him. He compares son with Lala Bholaram's son, who just retained his father's name to

the sweetmeat shop but changed to the worst. Hasmukh believes that his son would do the same and taint his name, if he refuses to take care of his words. Then he says that his wife is an idiot and useless as mud. He says that he has never got sexual satisfaction from his wife and he believes that his wife never enjoyed sex. He then started to have one night stand relationship with the posh locality, very close to his house. He says that his mistress alone has the brain to match him. He is of view that everyone in house is a herebrained mediocre idiot. That is why he is not satisfied by the role they play. He finds faults with them and dismisses them as idiots [3].

After the demise of Hasmukh the inmates of family find that they were tricked out of the inheritance by the will of Hasmukh Mehta for a period of twenty-two years. On hearing this Preeti behaves rudely with Ajit and Sonal out of the agony resulting from deprivation of expectations. Hasmukh has a formed Trust with his former mistress Kiran Jhaveri as its Trustee and he has made a provision in the Trust to give mearge monthly allowance to his family members as per his unique will.

Hasmukh tries to control his family even after his death. Even after his death his patriarchal authority knows no bounds. Ajit, Sonal and Preeti are shocked by the terms and conditions of the will. They find it as an insult to appoint Kiran Jhaveri the Trustee of the Hasmukh Mehta Charitable Trust.

\section{Conclusion}

Dattani broadly uses patriarchal code through his play. Where there's a Will shows the social realism through comic dialogues [6] The protagonist never allows his family members to live with smile 
Citation: Sankar G, Hephzhibah JS (2018) The Exploitation of Patriarchal Society with Reference to Mahesh Dattani's Where There's a Will Paradigm Shift. Arts Social Sci J 9: 383. doi: 10.4172/2151-6200.1000383

Page 4 of 4

and independence. Finally the ghost realizes the reality and goes out. The father-son relationship is discarded disharmoniously. All the women has been victimized and exploited by a patriarchal society. Even they suppressed in the society one day the world will recognise the importance of women in our country.

\section{References}

1. Agrawal B (2008) Mahesh Dattani's Plays: A New Horizon in Indian Theatre. (1stedn) Jaipur India: Book Enclave, p: 200
2. Dattani M (2000) Collected Plays, New Delhi: Penguin Books, India p: 459.

3. Dattani M (2005) Collected Plays, New Delhi: penguin Books 2: 480.

4. Hayman R (1969) No Time for Tragedy: Contemporary Playwrights. Quoted in Ronald Hayman. London: Heinemann.

5. Raina S (2000) A Note on the Play, Where There's a Will: In Collected Plays of Mahesh Dattani. New Delhi: Penguin Books, p: 451.

6. Menaka G, Sankar G (2017) Representing the Themes of Marginalization and Homosexuality in Mahesh Dattani's on a Muggy Night in Mumbai, International Journal of Research in Humanities and Social Studies. 4: 7-12. 